\title{
The Impact of Board Characteristics on Corporate Social Responsibility Disclosure: Evidence from Nigerian Food Product Firms
}

\author{
Muhammad Aminu Isa ${ }^{1}$, Sabo Muhammad ${ }^{2}$ \\ ${ }^{1}$ Department of Accounting, Bayero University, Kano, Nigeria \\ ${ }^{2}$ Department of Accountancy, Kano State Polytechnic \\ ${ }^{2}$ Email (corresponding author): sabomuhammad80@gmail.com
}

\begin{abstract}
This study examines the impact of Board Characteristics on Corporate Social Responsibility Disclosure of listed food product firms in Nigeria over the period 2005-2014. A sample of six firms out of eleven food product firms listed on the floor of Nigerian Stock Exchange was studied. The study made use of secondary data generated from Annual Reports and Accounts of the sampled firms and the Nigerian Stock Exchange Fact book. The data was analyzed by means of descriptive statistics, correlation and regression analysis using STATA (version 12) package. The study reveals that board size and women on board show a significant positive association with corporate social responsibility disclosure of the sample firms. While managerial ownership shows a significant negative effect on corporate social responsibility disclosure. However, board independence indicates an insignificant association with corporate social responsibility disclosure. While the control variable (Size) shows an insignificant negative relationship with corporate social responsibility disclosure. Based on the findings, the study recommends among others, that firms in the food product should have a competent size of 9 to 15 of board members, so as to encourage corporate social responsibility disclosure. Also, the proportion of non-executive directors on the board should be maintained and the appointment should be strictly based on experience and expertise as this will also ensure more corporate social responsibility disclosure. Also, women participation on the board should be encouraged as much as possible since women may have different skills compared to their men counterpart as this will help in ensuring full disclosure of all CSR related information.
\end{abstract}

Keywords:Board size, Board Independence, Managerial Ownership, Women Diversity, Food Product Firms.

\section{Introduction}

Corporate Social Responsibility (CSR) has become an important topic in academic writing and the business field. Many organizations or institutions worldwide strongly emphasize that firms must take into consideration the economic, social and environmental effects of their activities (World Business Council for Sustainable Development 2000; European Commission 2002; World Bank 2004). Corporate Social Responsibility Disclosure is a process of providing information about interactions between companies with regard to environment, employees, society and consumer issues (Gray et al. 2001). It is also a process of providing financial and non-financial information in the social and environment context (Hackston and Milne 1996). In addition, CSRD is an extension of the financial disclosure system, which reflects the wider anticipation of society concerning the role of the business community in the economy. CSRD includes all information reported to stakeholders about social and environmental effects of a company's actions. As such, it involves extending the accountability of company beyond the traditional role of providing a financial account to the owners of capital. This information could be of qualitative or quantitative nature or both and it may be reported in annual reports, a specific report, a media release or other form as a means of achieving company's objectives. (Adams \&Shavit, 2011). 
Effective board characteristics ensure maximum protection of shareholders interest, efficient monitoring and management of risk, as well as the provision of the effective control mechanism. In view of this companies are expected to report their economic, social and environmental performances to the appropriate stakeholders periodically. This is essential, as the boards of companies are responsible for ensuring effective control mechanism based on the approved conventionally-guided principles, specifically those that are associated with monitoring and management of risk, environmental and social liabilities inclusive. As CSRD is influenced by many factors, choices, motives and values of those involve in policy formulation and decision-making processes of formal organizations, Haniffa and Cooke (2005) argues in favour of considering the board characteristic mechanisms or composition, such as board size, board independence, managerial ownership and women on board as essential pre-requisite or determinant factors of CSRD. This argument shows the obvious role of board characteristics in the context of formal organizations.

Vo and Phan (2013) indicate that the board characteristics can be measured through multiple features: board size (BS), board independence (BI), managerial ownership (MOWN) and women on board (WB). These characteristics influenced the emergence of effective Board of Directors of a given company, and also influenced their understanding of the environmental and social consequences of company's action, as well as appropriate response to the divergent views of those that come into contact with the company. In addition, the board (based on effective characteristics mechanisms) is responsible for the setting of the standard of operating objectives, strategies, control mechanism and effective service delivery of the company in its capacity as the wealth creating organ of the society (Ali and Attan, 2013). It is, therefore, apparent that, the nature of board characteristics determines the effectiveness of the performance of the Board of directors, especially in discharging the CSR activities. In the same vain, scholars (Uwuigbe and Egbide, 2013; Vo and Phan, 2013 and Ali and Attan, 2013) maintain that, a sound CSRD through board characteristics policies help in improving financial performance, access capital, Increased sale, lower operating cost, increased customers loyalty, productivity and quality.

In Nigeria, the issue of board characteristics as a subset of corporate governance has been given special attention by all sectors of the economy because of the evidence of financial scandals that led to corporate failure such as in Cadbury Nigeria Plc, Oceanic Bank International, Intercontinental Bank, Afri-Bank among others in the last decade (s) and have been generating a lot of concern among scholars such instances precipitated the new trend of holding management and boards more accountable to their assigned responsibilities by the shareholders.

Accordingly, companies having effective board characteristics of board size, board independent, managerial ownership and participation of women on board are positively presumed to be better corporate citizens and more socially and environmentally responsible than companies with poor board characteristics. This indicates that there should be a strong positive association between board characteristics and CSRD of companies (Ali and Attan 2013). The objective of this study is to examine the impact of board characteristics with such variables as board size, board independence, managerial ownership and women diversity on corporate social responsibility disclosure with emphasis on Nigerian food product firms.

The rest of the paper is divided into four sections, section two brief literature from previous studies. Third section of the study describes methodology used for examining the impact of board characteristics on corporate social responsibility disclosure. Section four comprises of the empirical results and discussion. Fifth section is conclusion and recommendation.

\section{LiteratureReview}

This study considered four aspects of board characteristics (Board Size, Board Independent, Managerial Ownership and Women on Board) as related to corporate social responsibility disclosure. Corporate boards are responsible for monitoring the quality of information contained in the financial statements, thus they control the behaviour of senior managers in order to guarantee that their actions are aligned with the interests of stakeholders (Dimitropoulos and Asteriou, 2010). The role of corporate boards is therefore embedded in corporate governance practices with responsible boards fostering good corporate governance roles. From an agency theoretical perspective, boards with a high proportion of independent directors are presumed to be more effective in monitoring and controlling management. They are, therefore, expected to be more successful in directing management towards long-term firm value enhancing activities and a high degree of transparency. Independent directors are supposed to be able to assess management 
performance more objectively than executive directors, as they are less closely involved in the development of firm strategies and business policies. In addition, independent directors are less dependent on the CEO's goodwill than executive directors and affiliated non-executive directors with business links to the firm. Therefore, a higher proportion of independent directors on the board are expected to lead to better monitoring and control of management (John and Senbet, 1998; Ahmed et al., 2006; Cheng and Courtenay, 2006)

\subsection{Review of Related Empirical Literature}

Kurawa and Abdulrahman (2014), examine the effect of corporate governance on corporate social responsibility of the listed firms in the Nigerian petroleum marketing industry a sample of 5 companies were chosen for the period of 2002 2011. Panel Data Analysis was employed to test the hypotheses. Also, the study used board size, board composition, leadership structure, CEO duality and management equity holding as independent variables, while donation/contribution was used as dependent variable. Results revealed that corporate social responsibility activities in the Nigerian petroleum industry were positively driven mainly by management equity holding and to some extent by other attributes of CG; board size, board composition and CEO duality.

Similarly, Giannarakis (2014), investigated the effect of corporate governance and financial characteristics on the extent of corporate social responsibility disclosures. A sample of (100) companies listed in the US were studied for the year 2011. The variables used are CEO duality, board meeting, boards' average age, board composition and women on board and board size as proxy for independent variable, while board commitment to CSR, profitability and financial leverage was used as dependent variable. The study employed a Multiple Linear Regression using the statistical package of E-views to test the effect of a dependent variable on the independent variable. The result of the study indicated that board commitment to CSR and profitability were found to be positively related with the extent of CSR disclosure, while financial leverage was negatively related to the extent of CSR disclosure. The study was conducted outside Nigeria and time period covered was one year which is seen inadequate to give a valid result.

In the same vein, Bouaziz (2014) studies the relationship between corporate governance and voluntary financial disclosure of Canadian listed firms for the years 2003. Samples of 84 companies across 14 industries listed in the Canadian Stock Exchange were studied. The study employed Regression Analysis to test the relationship between the variables. The independent variables used were CEO duality, board size, ownership structure, board independence and audit committee. Also, the study introduced some control variables; leverage, size and quotation of foreign exchange. The findings showed that CEO duality and board size had a negative association with the level of firms' voluntary disclosure, while ownership structure was not a determinant of the level of voluntary financial disclosure in Canada. Also, Giannarakis et al. (2014), studies the financial, governance and environmental determinants of corporate social responsibility disclosure on 100 top companies listed in the US Stock Exchange for the period 2009-2012. A descriptive statistic and Correlation Matrix were used to measure the relationship. CEO duality and presence of women on board were used as a proxy of the independent variable, while social responsibility disclosure index was used as a measure of the dependent variable. The results showed that CEO duality was not a determinant of the extent of CSR disclosure.

Another study by Kurawa and Kabara (2014) examined the impact of corporate governance on voluntary disclosure by firms in the downstream sector of the Nigerian petroleum industry. A secondary data obtained from the Annual Report and accounts of the 7 sampled companies were used. The data was analysed by means of descriptive statistics and Regression Analysis using STATA package for the period 2001-2010. Board composition, managerial ownership, ownership concentration and role duality were used as a proxy of the independent variable. The study revealed that ownership concentration was one of the major determinants of corporate governance and had a significant positive association with the extent of voluntary disclosures. O The study showed a positive relationship with board composition. Also, managerial ownership and CEO duality showed a negative relationship with voluntary disclosure of the sampled firms.

Also, Said et al (2009) studied the relationship between corporate social responsibility disclosure and corporate governance characteristics in Malaysian public listed companies using a sample of 150 companies listed on the main board of Bursa Malaysia for the year 2006. The independent variable proxy by board size, board independence, CEO duality, audit committee, ten largest shareholders, managerial ownership, foreign ownership and government 
ownership and a control variable of size and profitability were used. The result of the study showed that government ownership and audit committee had a positive and significant correlation with the level of CSR disclosure, and that the most significant variable that influences the level of CSR disclosure was government ownership.

Similarly, Haji (2013) conducted a study on corporate Social Responsibility Overtime, in the study a sample of 85 companies listed on Bursa Malaysia for the years (2006 - 2009). A Multiple Regression Analysis and descriptive statistics were used. The study discovered that managerial ownership, government ownership and company size were discovered significant in explaining both the extent and quality of CSR disclosures. On the other hand, board size was discovered of significant relationship with the extent of CSR disclosures.

Khan, Muttakin\&Siddiqui (2013) studied the interaction between corporate governance and corporate social responsibility disclosures, a sample of 135 manufacturing firms listed in Dhaka Stock Exchange were studied. Managerial ownership, public ownership, board independence, foreign ownership, CEO duality and audit committee were used as a proxy for the independent variable while firm's age, size and return on assets (ROA) were used as control variables. The finding of the study showed that CSR disclosures generally had a negative association with managerial ownership. However, it was discovered that public ownership, foreign ownership, board independence and presence of audit committee had a positive significant impact on CSR disclosures, but CEO duality was discovered to have no significant impact on CSR disclosure.

Based on the literature reviewed it can be deduced that most of the studies were conducted outside Nigeria. The countries had different environmental context and disclosure requirements, in view of these, the findings of the various studies may not be appropriately relevant or having direct bearing with Nigerian setting. The current study examines the impact of board characteristics on corporate social responsibility disclosure in Nigerian food product firms. On the basis of these literatures done in different countries the researcher developed this methodology.

\section{Research Methodology}

The purpose of this research is to contribute towards a very important aspect of corporate governance known as board characteristics with reference to Nigeria. Here we will see the effect of board characteristics on corporate social responsibility disclosure of 6 food products Nigerian firms listed on the Nigerian stock Exchange for a period of ten years from 2005 - 2014. This section of the article discusses the firms and variables included in the study, the distribution patterns of data and applied statistical techniques in investigating the effect of board characteristics on corporate social responsibility disclosure.

The data for this study is collected using the non-survey method. This is due to the fact that the accounting information required for this study is easily obtainable from the published annual reports and accounts. Accordingly, relevant Directors report and statement of financial position items: the number of directors sit on the board, the proportion of non-executive directors on the board, the number of women sit on the board and managerial ownership of the sampled firms are the variable to be studied in this work.

\subsection{Population and sample size}

The population of this study is made up of all the quoted Nigerian food product companies quoted on the Nigerian Stock Exchange, their years of Incorporation and years of listing are as follows: 
Table 1: Study Population

\begin{tabular}{|l|l|c|c|}
\hline s/n & Company name & Year of incorporation & Year of listing \\
\hline 1 & FLOUR MILLS OF NIGERIA PLC & 1960 & 1979 \\
\hline 2 & N. N. F. M. PLC & 1971 & 1978 \\
\hline 3 & DANGOTE SUGAR REFINERY PLC & 2005 & 2007 \\
\hline 4 & NATIONAL SALT COMPANY PLC & 1973 & 1992 \\
\hline 5 & UNION DICON PLC & 1992 & 1993 \\
\hline 6 & MULTI-TREX PLC & 1999 & 2010 \\
\hline 7 & HONEY WELL FLOUR PLC & 2008 & 2009 \\
\hline 8 & DANGOTE FLOUR MILLS PLC & 2006 & 2008 \\
\hline 9 & BIG TREAT PLC & 1991 & 2007 \\
\hline 10 & PS MANDRIES & 1949 & 1979 \\
\hline 11 & UTC NIGERIA PLC & 1969 & 1972 \\
\hline
\end{tabular}

Source: Generated by the researcher from the NSE 2013/2014 fact book

Table 1 is about the total population of the study, out of which the working population is arrived at. The criteria used for choosing the working population are listing latest by 2005 and the availability of data for the period under study that is 2005 to 2014 . The companies met with these criteria are listed in table 2.

Table 2: Working Population

\begin{tabular}{|l|l|c|c|}
\hline s/n & Company name & Year of incorporation & Year of listing \\
\hline 1 & FLOUR MILLS OF NIGERIA PLC & 1960 & 1979 \\
\hline 2 & N. N. F. M. PLC & 1971 & 1978 \\
\hline 3 & NATIONAL SALT COMPANY PLC & 1973 & 1992 \\
\hline 4 & UNION DICON PLC & 1992 & 1993 \\
\hline 5 & PS MANDRIES & 1949 & 1979 \\
\hline 6 & UTC NIGERIA PLC & 1969 & 1972 \\
\hline
\end{tabular}

Source: Generated by the researcher from table 1.

\subsection{Variables}

The statistical method of OLS regression analysis was employed in the conduct of this study. This technique of data analysis is used in ascertaining the effects of the independent variables on the dependent variable. Choice and selection of variables is influence by the past research and different study conducted by different scholars on board characteristics.

\subsubsection{The dependent variable and its measurement}

The corporate social responsibility disclosure index (CSRDI) represents the dependent variable in this study. To assess the extent of CSR disclosure in annual reports, the content analysis was employed in stimulating data from the annual report. This is due to the fact that the content analysis method is the commonly used method of measuring corporate social responsibility disclosure in annual reports ( Haniffa and Cooke 2002, Ghazali 2007, Said et al 2009, Uwuigbe and Egbide 2012). Content analysis is a systematic replicable technique for compressing many words of text into fewer content categories based on explicit rules of coding (Montabon et al 2007). However, this study attempts to measure the CSR disclosure using a check list developed by Hannifa and Cooke, (2002) with modification. A dichotomous procedure is applied whereby a company is awarded 1 if an item included in the checklist is disclosed and 0 if it is not disclosed. Accordingly, the CSR disclosure index contained 15 attributes (Appendix A); a firm could score a maximum of 15 points and a minimum of 0 . The formula for calculating the reporting scores by using the corporate social responsibility disclosure index expressed in a function form: 


\section{$\mathrm{n}$

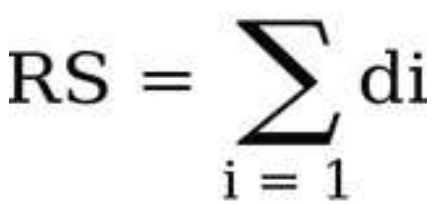

Where:

RS = Reporting Score

$\mathrm{di}=1$ if the item is disclosed; 0 if the item is not disclosed

$\mathrm{n}=$ Total items in the checklist i.e 15

$\mathrm{i}=1,2,3$ .15

\subsubsection{Explanatory variables}

The explanatory variables include the independent and control variables.

a) Independent Variables

These are the factors hypothesized to have influence on CSRD. These variables and their measurement are explained below in the context of this study.

i. Board size: - This refers to the number of directors sit on the board. A number of studies on board characteristics have used this variable as proxy. Kurawa and Abdulrahman (2014), Bouaziz (2014), Johl et al (2013), Jizi et al (2013), Ali and Attan (2013).

ii. Board independence: - It refers to the proportion of non-executive directors on the board. Jizi et al (2013), Khan, Muttakin\&Siddiqui (2013), Johl et al (2013), Haji (2014) and Taha (2013) have used this variable as a proxy of corporate governance. It is calculated as the proportion of non-executive directors divided by total number of directors on the board.

iii. Managerial Ownership: -This refers to the percentage of shares owned by the members of the board of directors to the total issued shares as used by Eng and Mak (2003), Sanda, Mika ${ }^{\text {ee } i l ~ a n d ~ T u k u r, ~ 2005), ~ K u r a w a ~}$ and Kabara (2014). It is calculated as shares owned by board members by total issued shares.

iv. Women on Board: - it refers to the number of women sitting on the board of directors as used by Coffey (1992), Khan (2010).

\section{b) Control variable}

The control variables included in the model is size. The size (SIZE) is measured by taking the natural Log of total assets. In addition, Watts and Zimmerman (1990) in Samaila (2014) argue that larger firms are likely to show more information in order to improve the confidence of stakeholders and reduce political cost. Studies of Bouaziz (2014), Johl et al (2013), Ali and Attan (2013) Jizi et al (2013) have used size as a control variable.

Table 3: Summary of the variables and their measurement

\begin{tabular}{|l|l|}
\hline Variables & Measurement \\
\hline CSR disclosure & Scoring of CSR disclosure index \\
\hline Board size(BS) & Number of directors sit on the board \\
\hline Board independence (BI) & $\begin{array}{l}\text { Proportion of non-executive directors divided by total number of directors on the } \\
\text { board of the company }\end{array}$ \\
\hline $\begin{array}{l}\text { Managerial ownership } \\
\text { (MOWN) }\end{array}$ & Proportion of shares owned by board members to the total issued shares. \\
\hline Women on board size (FSIZE) control & Number of women directors sit on the board \\
\hline $\begin{array}{l}\text { Firm logarithm of total assets } \\
\text { variable }\end{array}$ & \\
\hline
\end{tabular}




\subsection{Model Specification}

In order to evaluate the impact of board characteristics on corporate social responsibility disclosure, the study adopts with little modification the model used by Khan, Muttakin and Siddiqui (2013) as follows:

$\mathrm{CSRD}=a+\beta 1 \mathrm{BS}+\beta 2 \mathrm{BI}+\beta 3 \mathrm{MOWN}+\beta 4 \mathrm{WB}+\beta 5 F \mathrm{SIZE}+\varepsilon$

Where:

CSRDI $=$ Corporate Social Responsibility Disclosure Index

$\mathrm{BS}=$ Board Size

$\mathrm{BI}=$ Board Independence

MOWN = Managerial Ownership

$\mathrm{WB}=$ Women on Board

FSIZE $=$ Firm Size

$\mathrm{a}=$ Represent the fixed intercept element

$\boldsymbol{\varepsilon}=$ is error term

\section{Results and Discussion}

The statistical software of Stata (version 12) was used to analyse the impact between variables of the study. Descriptive statistic merely represents the statistical attributes of the variables in the study model. Table 4 below provides such statistics. All the variables were collected from the relevant information on directors' report and statement of financial position of the sampled companies.

Table 4: Descriptive Statistics of Variable

\begin{tabular}{lccccc}
\hline Variable & Min. & Max. & Mean & Std. Dev. & No. \\
\hline CSRD & O.1333 & 0.7333 & 0.4800033 & 0.1799037 & 60 \\
\hline BS & 6 & 15 & 9.4 & 2.54581 & 60 \\
\hline BI & 0.75 & 0.9333 & 0.8614867 & 0.484716 & 60 \\
\hline MOWN & 0.004 & 0.9416 & 0.2427617 & 0.3283838 & 60 \\
\hline WB & 0 & 0.14 & 0.0283333 & 0.0547155 & 60 \\
\hline SIZE & 4.8384 & 8.35 & 6.328138 & 0.9972621 & 60 \\
\hline
\end{tabular}

Source: Generated by the researcher from the Annual Reports and Accounts of the sampled companies, using Stata (version 12).

Table 4 revealed that corporate social responsibility disclosure of the firms in the Nigerian food product over the ten years period ranged from $13 \%$ to $73 \%$ and with average values of the dependent variable of $48 \%$ and the standard deviation of 0.1799037 indicating that on average, $48 \%$ of the observations disclosed CSR related information, it shows that the minimum disclosure is $13 \%$ while the maximum disclosure was $73 \%$. It is an indication that none of the firms disclosed all the CSR-related information. The average of Board size is 9.4 with the standard deviation of 2.545851 . The size of the board varies widely across the sample firms as the minimum and the maximum is 6 and 15 members respectively. The important factor that explains the large disparity of the size could be connected with the wide difference of the sample firm's sizes as represented by their total assets. Larger firms tend to have more directors on their boards, which is a reflection of the firms vast equity shareholding structure.

Board independence averages $86.15 \%$ of the size of board of directors with a standard deviation of $4.85 \%$, this indicate that on average $86.15 \%$ of board members of Nigerian food product firms were independent directors. The minimum percentage of outside directors is $75 \%$ and the maximum of $93 \%$. This statistics shows that all of the sample firms have fully complied with the corporate governance code guideline that firms should maintain at least $10 \%$ independent nonexecutive directors on their boards who are expected to assist in the oversight functions of the boards. Managerial 
ownership averages $24.28 \%$ and standard deviation of 0.3283838 with minimum of $4 \%$ and maximum of $94 \%$, this indicate that managerial ownership in the Nigerian food product firms vary significantly across the firms

Women on board show a mean of $3 \%$ with a standard deviation of 0.0547155 and with a minimum value of 0 and maximum of $14 \%$. This means that women are not participating much in the board of the Nigerian food product firms, the firms are not encouraging diversity in the board.

In an effort to establish the nature of the correlation between the dependent and the independent variables, and also to ascertain whether or not multi-collinearity exists as a result of the correlation between variables, table 5 is incorporated for the purpose of analysis. The correlation matrix in table 5 provides an insights into which of the independent variables are related to the dependent variable.

Table 5: Correlation Matrix of variables

\begin{tabular}{|c|c|c|c|c|c|c|}
\hline VARIABLES & CSRDI & BS & BI & MOWN & WB & SIZE \\
\hline CSRDI & 1 & & & & & \\
\hline BS & 0.5383 & 1 & & & & \\
\hline BI & 0.3066 & 0.2910 & 1 & & & \\
\hline MOWN & -0.7614 & -0.5236 & -0.4427 & 1 & & \\
\hline WB & 0.3627 & -0.3894 & 0.0418 & -0.2735 & 1 & \\
\hline SIZE & 0.6359 & 0.7106 & 0.5316 & -0.7045 & 0.0967 & 1 \\
\hline
\end{tabular}

Source: Generated by the researcher from the Annual Reports and Account of the sample using stata (version 12).

The correlation matrix as per table 5 above shows the relationship between all pairs of explanatory variables used in the regression model. It reveals that all the explanatory variables have a positive correlation with the dependent variable with the exception of MOWN that show a negative correlation. The positive correlations imply that as Board size (BS), Board independent (BI), Women on board (WB) and Size (SIZE) increases, the disclosure of corporate social responsibility also increases. On the other hand, Managerial ownership (MOWN) shows a negative correlation; as the managerial shareholding increases it affect the CSR disclosure negatively. The values on the diagonal are all 1.0000 which shows that each variable is perfectly correlated with itself. Though, all the explanatory variables are positively correlated with CSR disclosure with the exception of MOWN, this shows that as the BS, BI, WB and SIZE increases the CSR disclosure of the firms increases and vice versa. On the other hand, the negative relationship that exists between Managerial ownership and CSR disclosure indicate that they are negatively correlated.

The following table represents the results of TV and VIF for the board characteristics components.

Table 6: Multicollinearity Test

\begin{tabular}{llll}
\hline Variable & VIF & 1/VIF $($ TV $)$ & \\
\hline BS & 4.23 & 0.236224 \\
\hline SIZE & 4.05 & 0.246707 \\
\hline MOWN & 2.53 & 0.394979 \\
\hline WB & 2.26 & 0.442898 \\
\hline BI & 1.52 & 0.659495
\end{tabular}

Mean VIF 2.92

Source: Generated by the researcher from the Annual Reports and

Accounts of the sampled companies, using Stata (Version 12). 
From the table above TV ranges from 0.236224 to 0.659495 which suggests non multi-collinearity feature. Multicollinearity feature exists when the value of TV is less than 0.20 (as cited in Kurawa and Kabara, 2014). The VIF which is simply the reciprocal of TV range 1.52 to 4.23 , this indicates the absence of multi-collinearity.

Regression model was developed to test the impact of independent variable on the dependent variable. To test the quality of the linear fit to the model, the researcher calculated the coefficient of multiple as shown in the table below:

Table 7: OLS Regression

$\mathrm{CSRD}=-.2011139+.0452513 \beta_{1}+1.0169382 \beta_{2}-.2079987 \beta_{3}+1.7147390 \beta_{4}-.0251503 \beta_{5}+\varepsilon$

\begin{tabular}{|c|c|c|c|c|c|c|}
\hline CSRD & & Coefficients & & Std. Errors & $\mathrm{Z}$ & P> IZI \\
\hline $\mathrm{BS}$ & & 0.0452513 & & 0.0101712 & 4.45 & 0.000 \\
\hline $\mathrm{BI}$ & & 0.0169382 & & 0.3197231 & 0.05 & 0.958 \\
\hline MOWN & & -0.2079987 & & 0.0609816 & -3.41 & 0.001 \\
\hline WB & & 1.7147390 & & 0.3456251 & 4.96 & 0.000 \\
\hline SIZE & & -0.0251503 & & 0.0254078 & -0.99 & 0.322 \\
\hline Constant & & 0.2011139 & & 0.2698360 & 0.75 & 0.456 \\
\hline \multirow[t]{3}{*}{ R-square } & Within & & 0.0481 & & & \\
\hline & Between & & 0.9437 & & & \\
\hline & Overall & & 0.7357 & & & \\
\hline Probability & & & 0.0000 & & & \\
\hline
\end{tabular}

Source: Generated by the researcher from the Annual Reports and Accounts of the sampled companies, using Stata (Version 12).

The results of OLS show the coefficient of determination "R-Square" shows $73.57 \%$ indicating that the variables considered in the model account for about $73.57 \%$ change in the dependent variable that is CSR disclosure, while remaining of the change is as a result of other variables not addressed by this model. It denotes that $73.57 \%$ of total variation in corporate social responsibility disclosure of Nigerian listed food product firms is caused by their board size, board independence, managerial ownership of shares, women serve on the board and the size of the firms. This indicates that the model is fitted and the explanatory variable are properly selected, combined and used as the substantial value of the reporting quality is accounted for by the explanatory variables. Hence, the finding of the study can be relied upon.

In evaluating the model based on the OLS regression result in table 7. The result shows that the relationship between CSR disclosure and BS is positive and significant at $1 \%$, this can be justified with a positive ' $\mathrm{t}$ ' of 4.45 and $\mathrm{p}>|\mathrm{t}| 0.000$. Also, the positive coefficient of 0.0452513 is evidencing that, with an increase in BS by one person, while other variables remain constant there will be an increase in the firms CSR disclosure by 0.0452513 . This implies that, board size has a positive association with the level of CSR disclosure. This result is consistent with the findings of Jizi et al. (2013), Ali \&Attan (2013) and Haji (2014). But the results disagree with the findings of Taha (2013) Bouaziz (2014) and Kurawa and Kabara (2014).

Also, the relationship between CSR disclosure and BI is positive but insignificant, this can be justified through the positive ' $t$ ' value of 0.05 and $p>|t|$ of 0.958 , it has also been confirmed by the positive coefficient of 0.0169382 , which means that an increase in BI by one more person, other variable remaining constant increases the firms CSR disclosures by 0.0169382 . This implies that BI has an insignificant positive relationship with the CSR disclosure. This finding is in agreement with the findings of Taha (2013) and Khan, Muttakin and Siddiqui (2013) who discovered that board independence has a positive association with the CSR disclosure.

However, the relationship between CSR disclosure and MOWN is negative and significant at $1 \%$ this is evidenced by the negative ' $t$ ' value of -3.41 and $\mathrm{p}>|\mathrm{t}|$ of 0.001 also a negative coefficient of -0.2079987 . This means that as the 
managerial ownership is increasing while other variables remain constant decreases the level of CSR disclosure and vice versa. This result shows an inverse relationship between MOWN and CSR disclosure. This result is consistent with the findings of Eng and Mak (2003), Said et al (2009), Khan, Muttakin and Siddiqui (2013) Taha (2013). The result also shows that the relationship between WB and CSR disclosure is positive and significant at $1 \%$, this can be justified with a positive ' $\mathrm{t}$ ' of 4.96 and $\mathrm{p}>|\mathrm{t}|$ 0.000. Also, the positive coefficient of 1.7147390 has proven that, with an increase in WB by one person, while other variables remain constant there will be an increase in the firms CSR disclosure by 1.7147390 . This implies that, as more women serve on the board will increases CSR disclosure of listed Nigerian food product firms. This result is consistent with the findings Wang \& Coffey (1992) and Bear, Rahman\& Post (2010). It is important to note that an increase in the proportion of women on the board increases the level of CSR disclosure. Similarly, the control variable of SIZE shows negative and insignificant association with the level of CSR disclosure, this can be justified with a negative ' $t$ ' value of -0.99 and $p>|t|$ of 0.322 and confirmed by the negative coefficient of -0.0251503

\section{Conclusion and Recommendations}

The need for good corporate governance arises because in corporations, the owners (who are also providers of funds) are usually separate from managers of such corporation even when the owners of corporation form part of the management (especially in the Board of Directors, as is the case of when institutional investors own controlling shares in the company), there is need to protect the interest of individual stakeholders. Board characteristics are also seen to have a positive association with the level of corporate social responsibility disclosure. The study finds that Board size, board independence and women diversity in the board are having a positive relationship with CSR disclosure in the Nigerian food product firms. The implication of this findings are that it provides evidence to the society, investors and regulators that larger boards are associated with the CSR disclosure in Nigerian food product firms, also as more women are appointed on the board brings among others to the organization such thing as prestige, skills, knowledge, and connection to external resources, another implication independent directors will reduce the conflict between owners and managers of resources and ensure a fair playing ground for all stakeholders since they are appointed on merit.

On the basis of the findings of the study the paper conclude that Board size is an important determinant of CSR disclosure and its optimality, therefore, is essential for a better result. It is therefore concluded that larger board sizes are more likely to be versatile than a smaller one because they have expertise from various angles that mobilize recourses for optimal utilization and such larger board size should be encourage. Also, the number of independent (Non- executive) directors on the board is an important monitoring and control device. This is because the independent directors have the ability to monitor and control the extremes of the executive directors, thereby protecting and defending the interests of the shareholders and other stakeholders. In addition, they are free from managerial influence and capable of monitoring them effectively which improve the level of CSR disclosure in the Nigerian food product firms. Managerial ownership of shares decreases the level of CSR disclosure among the Nigerian food product firms. The presence of women on the boards of Nigerian food product firms can enhance ratings for CSR and corporate reputation sending vital signals to stakeholders. Hence, women participation on the boards increases the level of CSR disclosure.

Hence, the study recommends among others that competent board size 9 to 15 members should be put in place by owners/shareholders of the Nigerian food product firms to direct the affairs of the firms. Large board sizes are more versatile than a smaller one because they have expertise from various angles that mobilize re courses for optimal utilization, and such larger board size should be encouraged. Also, the women participation on the boards of the Nigerian food product firms should be encouraged as much as practicable since women may have different skills compared to their men counterpart, so incorporating more women on the boards help in ensuring full disclosure of all CSR related information. Therefore, it is suggested that further research be conducted on the same topic with different sector or industry, and incorporate other board characteristics not addressed in this study. 


\section{References}

- Adam, A. M., \& Shavit, T. (2009). Roles and responsibilities of boards of directors revisited in reconciling conflicting stakeholders interest while maintaining corporate responsibility. Journal of Management \& Governance, 13(4), 281-302.

- Ahmed, K., Hossain, M., \& Adams, M. (2006). the effect of board composition and board size on the informativeness of annual accounting earning. Corporate governance An international review, 14(5), 418-431.

- Ali, M. A., \& Attan, R. H. (2013). The relationship between corporate govaernance and corporate social responsibility disclosure: A case of Malaysian sustainability companies and global sustainability companies. south east Asia journal of contemporary business, economics and Law, 1(3), 39-48.

- $\quad$ Bear, S., Rahman, N., \& Post, C. (2010). The impact of board diversity \& gender composition on corporate social responsibility \& firm reputation. Journal of Business Ethics, 97(2), 207-221.

- Bouaziz, M. Z. (2014). Corporate governance and voluntary financial disclosure by Canadian listed firms. Management review, 9(1).

- Cheng, \& Courtenay. (2006). Board composition, regulatory regime and voluntary disclosure. International journal of accounting, 41(3), 262-289.

- Coffey, B. S., \& Wang, J. (1998). Board diversity \& managerial control as predictors of corporate social performance. Journal of Business Ethics, 17(14), 1595-1603.

- Dimitropoulos, E. P., \& Asteriou, D. (2010). The effect of board composition on the informativeness and quality of annual earnings: empirical evidence from Greece. Research in International Business and Finance, 24, 190-205.

- Eng, L. L., \& Mak, Y. T. (2003). Corporate governance and Voluntary disclosure. Journal of Accounting and Public policy, 22(4), 325-345.

- Ghazali, N. A. (2007). Ownership structure and corporate social responsibility disclosure: Some Malaysian evidence. Corporate Governance, 7(3), 251-266.

- Giannarakis, G., Konteos, G., \& Sarriannidis, N. (2014). Fianacial, Govarnance and enviromental Determinants of Corporate Social Responsibility Disclosure. Management decision, 52(10), 1928-1951.

- Gray, R., Javad, M., Power, D. M., \& Sinclair, C. (2001). Social and enviromental disclosure and corporate characteristics: A research note and extension. Journal of Business Finance \& Accounting, 28(3), 327-356.

- Hackston, D., \& Milne, M. J. (1996). Some determinent of social and enviromental disclosures in New Zealand companies. Accounting, Auditing \& Accountability Journal, 9(1), 77-108.

- Haji, A. A. (2013). Corporate Social Responsibility Disclosure Overtime: Evidence from Malaysia. Managerial Auditing Journal, 28(7), 647-676.

- Haniffa, R. M., \& Cooke, T. E. (2002). Culture, corporate governance and disclosure in Malaysian corporations. Abacus, 38(3), 317-349.

- Haniffa, R. M., \& Cooke, T. E. (2005). The Impact of Culture and Governance on Corporate Reporting. Journal of Accounting and Public Policy, 24(5), 391-430.

- izi, M. I., Salama, A., Dixon, R., \& Stratling, R. (2013). Corporate Governance and Corporate Social responsibility Disclosure: Evidence from the US Banking sector. Business Ethics, 601-615.

- Johl, s. K., Kaur, S., \& Cooper, B. J. (2013). Board characteristics and firm performance: Evidence from Malysian punlic listed firms.

- John, K., \& Senbet, L. W. (1997). Corporate Governance and Board Effectiveness. Department of Finance Working Paper series.

- Khan, A., Muttakin, M. B., \& Siddiqui, J. (2013). Corporate Governance and Corporate Social Responsibility Disclosures: Evidence from an Emerging Economy. Business Ethics, 207-223.

- Khan, S. (2010). Corporate social performance in Indian FMCA companies. Issues in Social \& Enviromental Accounting, 3(2).

- Kurawa , J. M., \& Kabara, A. S. (2014). Impact of Corporate Governance on Voluntary Disclosure by Firms in the Downstream Sector of the Nigerian Petroleum Industry. Proceedings of World Business Research Conference, (pp. 1-19). Novotel World Trade Centre, Dubai, UAE, ISBN: 978-1-922069-48-1. 
- Kurawa, J. M., \& Abdulrahman, S. (2014). Effect of Corporate Governance on Corporate Social Responsibility of Listed Firms in the Nigerian Petroleum Marketing Industry. Proceedings of International Conference on Humanities, Science and Sustainable Development, 5(2), 27-35.

- Said, R., Zainuddin, y. H., \& Haron, H. (2009). The Relationship Between Corporate Social Responsibility Disclosure and Corporate Governance Characteristics in Malaysian Public Listed Companies. Social Responsibility Journal, 5(2), 212-226.

- Samaila, I. A. (2014). Corporate Governance and Financial Reporting Quality in the Nigerian Oil Marketing Industry. (Unpublished Doctoral Thesis) Bayero University, Kano-Nigeria.

- Sanda, A. U., Mikailu, A. S., \& Garba, T. (2005). Corporate Governance Mechanisms and Firm Financial Performance in Nigeria". AERC Research Paper 149, Nairobi, Kenya.

- Taha, M. H. (2013). The Relationship between Corporate Social Responsibility Disclosure and Corporate Governance Characteristics in Malaysian Public Listed Companies. 5B Learning Centre, 1.

- Uwuigbe, U., \& Egbide, B. (2012). Corporate social responsibility disclosure in Nigeria: A study of listed financial and non-financial firms. Journal of Management Sustainability, 2(1), 160-169.

- Vo, H. D., \& Phan, B. T. (2013). The relationship between Corporate Governance and Firm Performance. Unpublished Paper, Ho Chi Minh City Open University. 